\title{
Semi-aerobic stabilized landfill leachate treatment by ion exchange resin: isotherm and kinetic study
}

\author{
Mohd Faiz Muaz Ahmad Zamri • Mohamad Anuar Kamaruddin • \\ Mohd Suffian Yusoff • Hamidi Abdul Aziz • Keng Yuen Foo
}

Received: 29 August 2013/ Accepted: 21 January 2015/Published online: 10 March 2015

(C) The Author(s) 2015. This article is published with open access at Springerlink.com

\begin{abstract}
This study was carried out to investigate the treatability of ion exchange resin (Indion MB $6 \mathrm{SR}$ ) for the removal of chromium (VI), aluminium (III), zinc (II), copper (II), iron (II), and phosphate $\left(\mathrm{PO}_{4}\right)^{3-}$, chemical oxygen demand (COD), ammonia nitrogen $\left(\mathrm{NH}_{3}-\mathrm{N}\right)$ and colour from semi-aerobic stabilized leachate by batch test. A range of ion exchange resin dosage was tested towards the removal efficiency of leachate parameters. It was observed that equilibrium data were best represented by the Langmuir model for metal ions and Freundlich was ideally fit for $\mathrm{COD}, \mathrm{NH}_{3}-\mathrm{N}$ and colour. Intra particle diffusion model, pseudo first-order and pseudo second-order isotherm models were found ideally fit with correlation of the experimental data. The findings revealed that the models could describe the ion exchange kinetic behaviour efficiently, which further suggests comprehensive outlook for the future research in this field.
\end{abstract}

Keywords Resin - Landfill leachate - Adsorption · Isotherms · Kinetics

\section{Introduction}

Despite rapid changes of landfill technology from uncontrolled dump site to a highly engineered landfill for ultimate solid waste disposal method, generation of heavily polluted leachate remains inevitable (Cortez et al. 2011). Poorly managed inefficient landfilling has been seen as the

M. F. M. A. Zamri · M. A. Kamaruddin .

M. S. Yusoff $(\bowtie) \cdot$ H. A. Aziz $\cdot$ K. Y. Foo

School of Civil Engineering, Universiti Sains Malaysia, Engineering Campus, 14300 Nibong Tebal, Penang, Malaysia e-mail: suffian@usm.my major factor contributing to hydro geological contamination that originates from leachate that infiltrates into soil and groundwater. Furthermore, leachate is a heterogeneous mixture of high-strength organic and inorganic contaminants including humic acids, xenobiotic organic compounds (XOCs), ammonia nitrogen, heavy metals and other inorganic salts (Honjiang et al. 2009). If not properly treated and securely disposed, landfill leachate may bring potential hazards to surface and groundwater as it may percolate through soils and sub-soils. Therefore, treatment of landfill leachate is considered crucial prior to its discharge that can safeguard surrounding environment (Tatsi et al. 2003).

Even though the quantity of the leachate is lesser than other wastewaters, its contents are extremely hazardous (Al-Hamadani et al. 2011). In fact, landfill leachate continues to be dangerous and poisonous over long periods, particularly for ammoniacal nitrogen that leads to stimulated algae growth, accelerated eutrophication, enhanced dissolved oxygen depletion and increased toxicity for living organism in water body (Aziz et al. 2004; Karadag et al. 2008). Consequently, it is vital to determine appropriate treatment method to cope with the changing quality and quantity of the leachate over times (Bashir et al. 2011). Depending on the choice of treatment method, the applicability, efficiency and economic benefit of landfill leachate treatment mostly depend on the type of leachate characteristics and landfill design. Generally, biological treatments such as aerobic, anaerobic, sequencing batch reactor, aerated lagoons, and activated sludge are effective in removing organic matters in the early stages (from young leachate) when the $\mathrm{BOD}_{5} / \mathrm{COD}$ ratio is greater than 0.4 (Kurniawan et al. 2006; Renou et al. 2008). On the contrary, biological treatment is inefficient when it comes to the treatment of stabilized leachate due to the narrow 
range of biodegradable components in leachate, the presence of substances toxic for the microorganism and the limited availability of necessary nutrients for microbial growth (Li et al. 1999). Therefore, physico-chemical processes usually applied to treat persistent refractory compounds in stabilized leachate (Kamaruddin et al. 2014). Having said that, a wide spectrum of physico-chemical treatments have been tested including coagulation/flocculation, chemical oxidation, adsorption, chemical precipitation, membrane filtration as well as ion exchange process. Ion exchange process is widely used in water and wastewater treatment for extraction, separation, and purification of organic substances (Zagorodni 2006). Until now, a number of studies have been focused to remove ammonia and metal ions from water and wastewater using ion exchange resins, such as $\mathrm{NH}_{3}-\mathrm{N}$ from wastewater, $\mathrm{NH}_{3}-\mathrm{N}$ and nitrate from fertilizer factory wastewater, $\mathrm{NH}^{4+}$ ions from water, $\mathrm{Cr}$ from industrial effluents, $\mathrm{Cd}$ (II) and $\mathrm{Ni}$ (II) from landfill leachate and $\mathrm{Cu}^{2+}, \mathrm{Ni}^{2+}, \mathrm{Cd}^{2+}, \mathrm{Zn}^{2+}, \mathrm{Ca}^{2+}, \mathrm{Na}^{+}$, $\mathrm{Zn}^{2+}, \mathrm{Cr}^{3+}$ and $\mathrm{Cr}^{6+}$ from mixed plating rinse wastewater Leakovic et al. 2000; Cavaco et al. 2007; Jorgensen and Weatherley 2003; Kiefer et al. 2007).

However, until now, studies concerning removal of heavy metals $\mathrm{COD}, \mathrm{NH}_{3}-\mathrm{N}$ as well as colour from semiaerobic stabilized landfill leachate using ion exchange resin in the main treatment process remain limited and not well documented. The same is true for studies pertaining to the isotherms, kinetic models as well as breakthrough curves of ion exchange treatment. Thus, this study evaluated the treatability of stabilized semi-aerobic landfill leachate treatment via ion exchange resin (Indion MB 6 SR).

\section{Materials and method}

\section{Leachate samples}

In this study, the leachate sample was obtained from Pulau Burung Landfill Site (PBLS), which is situated within Byram Forest Reserve in Penang, Malaysia. The site was chosen because it has been developed semi-aerobically with leachate recirculation and it is one out of the only three sites of its kind in Malaysia. The site receives 1800 tonnes of domestic waste daily originating from Penang Island and Perai district. In 2001, the landfill was upgraded to a Level III sanitary landfill with controlled tipping and leachate recirculation (Aziz et al. 2010). Characteristically, PBLS has surpassed more than 20 years of operation and is currently experiencing methanogenic phase. As a result, the leachate produced is referred to as mature, "stabilized" leachate (Bashir et al. 2009). The dark brown coloured liquid, with high concentrations of COD and ammonium and a low $\mathrm{BOD}_{5} / \mathrm{COD}$ ratio is another
Table 1 Characteristics of stabilized leachate from Pulau Burung Landfill Site

\begin{tabular}{|c|c|c|c|}
\hline Parameter & Min & Max & Average \\
\hline Temperature $\left({ }^{\circ} \mathrm{C}\right)$ & 28 & 30 & 30.00 \\
\hline BOD $(\mathrm{mg} / \mathrm{L})\left(5\right.$ days@ $\left.20^{\circ} \mathrm{C}\right)$ & 8 & 1020 & 209.38 \\
\hline $\mathrm{COD}(\mathrm{mg} / \mathrm{L})$ & 879 & 3363 & 1800.80 \\
\hline $\mathrm{BOD} / \mathrm{COD}$ & 0.01 & 0.33 & 0.11 \\
\hline $\mathrm{pH}$ value & 7.38 & 8.78 & 8.09 \\
\hline Colour & 1455 & 1761 & 1586 \\
\hline Suspended solids (mg/L) & 45 & 695 & 174.90 \\
\hline Ammonia nitrogen $(\mathrm{mg} / \mathrm{L})$ & 54.3 & 1426.3 & 726.68 \\
\hline Arsenic (mg/L) & 0.1 & 0.1 & 0.10 \\
\hline Cadmium (mg/L) & 0.02 & 0.05 & 0.03 \\
\hline Lead (mg/L) & 0.02 & 1.6 & 0.29 \\
\hline Copper (mg/L) & 0.06 & 0.8 & 0.25 \\
\hline Manganese (mg/L) & 0.2 & 1.2 & 0.81 \\
\hline Chromium $+6(\mathrm{mg} / \mathrm{L})$ & 0.07 & 0.07 & 0.07 \\
\hline Chromium $+3(\mathrm{mg} / \mathrm{L})$ & 0.05 & 0.4 & 0.13 \\
\hline Nickel (mg/L) & 0.1 & 0.4 & 0.20 \\
\hline Tin $(m g / L)$ & 0.1 & 0.4 & 0.15 \\
\hline Zinc (mg/L) & 0.1 & 3.7 & 0.79 \\
\hline Boron $(\mathrm{mg} / \mathrm{L})$ & 0.6 & 7.7 & 3.58 \\
\hline Iron $(\mathrm{mg} / \mathrm{L})$ & 0.07 & 9.5 & 5.31 \\
\hline Phenol (mg/L) & 0.01 & 6.8 & 0.53 \\
\hline Sulphate $(\mathrm{mg} / \mathrm{L})$ & 0.1 & 2.8 & 1.45 \\
\hline Oil and grease $(\mathrm{mg} / \mathrm{L})$ & 1 & 41 & 10.65 \\
\hline
\end{tabular}

indicator of stabilized leachate. The leachate sample was collected from September 2010 until March 2011. During sampling period, $20 \mathrm{~L}$ of stabilized leachate were sampled using Teflon containers. The leachate sample was collected from a retention pond near to active phase of landfill bed and this routine was repeated twice per month for 6 months. The samples were transported to the laboratory and stored in a cold room at $4{ }^{\circ} \mathrm{C}$ to minimize biological and chemical changes prior to the experimental use (Bashir et al. 2010). The sampling procedure and preservation of samples were done according to the Standard Methods for the Examination of Water and Wastewater (APHA 2005). Without pretreatment, the samples were stored in cold room at $4{ }^{\circ} \mathrm{C}$ to minimize biological and chemical changes prior to the experimental use. Treated leachate samples were filtered using $0.45 \mu$ GC-50 glass micro fibre filters (Advantec, Japan) to retain fines particles from passing through prior to analytical measurement. Table 1 lists out the characteristics of stabilized leachate from PBLS.

Ion exchange resin

Indion MB 6 SR, a commercially available and economically reasonable resin (cation and anion), procured 
Table 2 Indion MB 6 SR mixed bed ion exchange physical properties

\begin{tabular}{ll}
\hline Product name & Indion MB 6 SR \\
\hline Applications & $\begin{array}{l}\text { Super regenerated mixture of highly reactive } \\
\text { resin for producing ultrapure water } \\
\text { Crosslinked polystyrene }\end{array}$ \\
Matrix type & $\begin{array}{l}\mathrm{SO}_{3}- \\
\text { Functional groups }\end{array}$ \\
& $\mathrm{NR}_{3}^{+}$ \\
Standard ionic form & $\mathrm{H}^{+}$ \\
& $\mathrm{OH}^{+}$ \\
Particle size range & $0.3-1.2$ \\
(mm) & \\
Max. Operating & 60 \\
Temperature $\left({ }^{\circ} \mathrm{C}\right)$ & \\
\hline
\end{tabular}

from Ion Exchange (India) Ltd, was utilized as parent resin towards the stabilized leachate treatment. Its particle size ranges from 0.3 to $1.2 \mathrm{~mm}$ with the maximum operating temperature of $60{ }^{\circ} \mathrm{C}$. Table 2 lists out specifications of the resin. For the purpose of pre-conditioning, the resins were first extensively backwashed with DI water to remove fines and low-density beads. This was followed by two cycle exhaustions carried out using $2 \mathrm{M}$ sodium hydroxide and $2 \mathrm{M}$ hydrochloric acid with intermediate and finally DI water rinses. Resins were then transferred into a clean polyethylene container and dried in a desiccator to prevent humidity and contaminants from seeping in.

Kinetic and isotherms studies

Preliminary tests using varying agitation speeds showed that $350 \mathrm{rpm}$ was high enough to well suspend the ion exchange resin, to eliminate the external mass-transfer resistance. For the entire experiments, $350 \mathrm{rpm}$ was chosen as the agitation speed. In the study, $250 \mathrm{~mL}$ conical flasks containing $120 \mathrm{~mL}$ of leachate samples were agitated on an orbital shaker with varying amount of resin (from 4 to $20 \mathrm{~cm}^{3}$ ). At the end of the pre-determined time interval, the adsorbent was removed by filtration and the ion concentrations were determined.

The data were then fitted with Langmuir and Freundlich adsorption isotherm models. The kinetic parameter study, which is helpful for the prediction of adsorption rate, was performed based on pseudo first-order, pseudo secondorder and intraparticle diffusion models, respectively. Equations for Langmuir and Freundlich adsorption isotherms models are represented by Eqs. (2.1) and (2.2). Briefly, $q_{\mathrm{e}}$ refer to amount adsorbed at equilibrium in the resin phase $(\mathrm{mg} / \mathrm{g})$, where $Q_{\mathrm{o}}, K_{\mathrm{L}}, K_{\mathrm{f}}, C_{\mathrm{e}}$ and $q_{t}$ refer to saturated amount of metal exchanged at given solution conditions $(\mathrm{mg} / \mathrm{g})$. Langmuir constant $(\mathrm{ml} / \mathrm{mol})$ related to energy of adsorption. Meanwhile, Freundlich isotherm constant $(\mathrm{ml} / \mathrm{mol})$ related to the adsorption capacity, equilibrium metal concentration in the solution phase ( $\mathrm{mol} /$ $\mathrm{ml}$ ) and amount of adsorbed in the resin phase at any time $t(\mathrm{mg} / \mathrm{g})$. In terms of kinetic equations, pseudo first-order, pseudo second-order and intraparticle diffusion models are expressed as Eqs. (2.3), (2.4) and (2.5), respectively. Meanwhile, $1 / n$ is the Freundlich isotherm constant $(\mathrm{ml} / \mathrm{mol})$ related to adsorption capacity, where $k_{1}, k_{2}, k_{\mathrm{id}}$ and $t$ individually represent the first-order constant $(\mathrm{g} /$ mg.min), second-order constant (g/mg.min) and rate constant for intraparticle diffusion (1/min) and time $\mathrm{min})$.

Parameters of the study

This research was limited to nine parameters, which were chromium (VI), aluminium (III), zinc (II), copper (II), iron (II) and phosphate $\left(\mathrm{PO}_{4}\right)^{3-}$, chemical oxygen demand (COD), ammonia nitrogen $\left(\mathrm{NH}_{3}-\mathrm{N}\right)$ and colour. Because the lot of variables involved in the batch test, preliminary of experiment has been carried out to minimize the effects of uncontrolled factors. Throughout the batch equilibrium test, leachate volume was fixed at $120 \mathrm{~mL}$, resin dosage was varied between 4 and $20 \mathrm{~cm}^{3}$ and contact time of $30 \mathrm{~min}$ was fixed to establish isotherm models. Meanwhile, for kinetic studies, the contact time was varied between 0 and $120 \mathrm{~min}$, resin dosage was varied between 4 and $20 \mathrm{~cm}^{3}$ and the others variables were kept constant.

Sample analysis

The treated samples were analysed using DR 2010 spectrophotometer (HACH, USA). The performance of separation for the heavy metals, ammonia nitrogen and COD was evaluated by the phenanthroline method. The analysis was conducted according to $\mathrm{HACH}$ recommendation with wavelength of $510 \mathrm{~nm}$ (method 8000), $455 \mathrm{~nm}$ (method 8025), $425 \mathrm{~nm}$ (method 8038), $510 \mathrm{~nm}$ (method 8146), $560 \mathrm{~nm}$ (method 8506), $620 \mathrm{~nm}$ (method 8009), $540 \mathrm{~nm}$ (method 8023), $522 \mathrm{~nm}$ (method 8012) and $890 \mathrm{~nm}$ (method 8048), respectively, for the analysis of $\mathrm{COD}$, colour, ammonia nitrogen, ion $\mathrm{Fe}^{2+}$, ion $\mathrm{Cu}^{2+}$, ion $\mathrm{Zn}^{2+}$, ion $\mathrm{Cr}^{6+}$, ion $\mathrm{Al}^{3+}$ and ion $\left(\mathrm{PO}_{4}\right)^{3-}$ concentration.

\section{Results and discussion}

Stabilized landfill leachate characteristics

Table 1 illustrates some of the leachate characteristics at PBLS. Even though the samples were collected on different days or at different times, the leachate characteristics demonstrate similar trend and were largely comparable for most of the parameters. The average $\mathrm{pH}$ value of the 
leachate samples is 8.09. According to (Umar et al. 2010), the $\mathrm{pH}$ of young leachate was less than 6.5 while for old landfill the leachate has $\mathrm{pH}$ higher than 7.5. Initial low $\mathrm{pH}$ was due to high concentration of volatile fatty acids (VFAs). Also, stabilized leachate shows fairly constant $\mathrm{pH}$ with little variations and it may range between 7.5 and 9 . The presence of significant amount of $\mathrm{NH}_{3}-\mathrm{N}(727 \mathrm{mg} / \mathrm{L})$ in the leachate demonstrated degradation of soluble nitrogen due to the decomposed waste. As a result, the concentration of $\mathrm{NH}_{3}-\mathrm{N}$ increases with the increase in age of the landfill which was due to hydrolysis and fermentation of nitrogenous fractions of biodegradable refuse substrate (Umar et al. 2010). Higher concentration of $\mathrm{NH}_{3}-\mathrm{N}$ enhances algae growth and promotes eutrophication due to decrease in dissolved oxygen content. Further, nitrification also leads to motivated algal growth, decreased performance of biological treatment systems, accelerated eutrophication, promoted dissolved oxygen depletion and increased toxicity for living organisms in water bodies (Aziz et al. 2010). The average values for $\mathrm{BOD}_{5}$ and COD were 209 and $1800 \mathrm{mg} / \mathrm{L}$, respectively. The calculated $\mathrm{BOD}_{5} / \mathrm{COD}$ ratio of 0.11 indicated that the changes in the amount of biodegradable compounds in the leachate (Warith 2002). The $\mathrm{BOD}_{5} / \mathrm{COD}$ ratio showed that the leachate was poorly biodegradable. The low $\mathrm{BOD}_{5} / \mathrm{COD}$ ratio $(0.11)$ also demonstrated that the leachate was stable and difficult to be further degraded biologically (Foul et al. 2009). From the table, high value of $\mathrm{pH}$ and low concentrations of $\mathrm{COD}, \mathrm{BOD}_{5}$ and heavy metals indicate that the leachate was in the phase of methane fermentation and classified as anaerobic phase (Salem et al. 2008). Normally, the concentration of heavy metals in leachate at the early stage of landfill operation are high due to higher metal solubility and dissociation of organic acids (Kulikowska and Klimiuk 2008). The colour concentration was reported as $1586 \mathrm{mg} / \mathrm{L}$ which is due to the low biodegradability of dissolved organic constituents in the leachate (Kamaruddin et al. 2013). Therefore, dark coloured liquid is an indicator of saturated organic content in the leachate. Overall, the leachate characteristics did not meet the permissible limit declared under Environmental Quality (Control of Pollution From Solid Waste Transfer Station and Landfill) Regulations 2009 (PU(A) 433) Second Schedule (Regulation 13) by Department of Environment, Malaysia.

\section{Adsorption isotherm}

\section{Langmuir isotherm}

Adsorption isotherm is the most important information to indicate how adsorbate molecules distribute between the liquid phase and solid phase when adsorption process reaches an equilibrium state (Lee et al. 2006). The study
Table 3 List of adsorption constants on Indion MB 6 SR resin for different adsorbates using Langmuir isotherm model

\begin{tabular}{llcll}
\hline Adsorbate & $\begin{array}{l}\text { Correlation } \\
\text { coefficient, } R^{2}\end{array}$ & \multicolumn{2}{l}{ Langmuir constants } \\
\cline { 3 - 5 } & & $Q$ o & $K_{\mathrm{L}}(\mathrm{L} / \mathrm{mg})$ & $R_{\mathrm{L}}$ \\
\hline${\text { Ion } \mathrm{Cr}^{6+}}^{6+}$ & 0.8796 & $2.678 \mathrm{mg} / \mathrm{mg}$ & 0.838 & 0.308 \\
$\mathrm{Ion}^{3+}$ & 0.8543 & $2.857 \mathrm{mg} / \mathrm{mg}$ & 0.821 & 0.299 \\
${\text { Ion } \mathrm{Cu}^{2+}}^{2+}$ & 0.9714 & $8.058 \mathrm{mg} / \mathrm{mg}$ & 0.335 & 0.270 \\
Ion $\mathrm{Zn}^{2+}$ & 0.8734 & $1.720 \mathrm{mg} / \mathrm{mg}$ & 0.821 & 0.414 \\
Ion $\mathrm{Fe}^{2+}$ & 0.8513 & $6.146 \mathrm{mg} / \mathrm{mg}$ & 0.167 & 0.493 \\
Ion $\mathrm{PO}_{4}{ }^{3-}$ & 0.3217 & $64.935 \mathrm{~g} / \mathrm{mg}$ & 0.032 & 0.325 \\
$\mathrm{COD}$ & 0.3224 & $2.204 \mathrm{~g} / \mathrm{mg}$ & 0.017 & 0.964 \\
$\mathrm{NH}_{3}$ & 0.7594 & $9.814 \mathrm{~g} / \mathrm{mg}$ & 2.010 & 0.048 \\
$\mathrm{Colour}$ & 0.4003 & $1.297 \mathrm{~g} / \mathrm{mg}$ & 0.468 & 0.622 \\
\hline
\end{tabular}

reviewed that the Langmuir fit for ion metals is good with correlation coefficient $R^{2}$ in the range of 0.85-0.97. Maximum monolayer adsorption capacity $Q_{\mathrm{o}}$ of Indion MB 6 SR mixed bed resin was found to proportionally increased as the amount of resin dosage also increased. In this context, adsorption capacity for ion $\mathrm{Cr}^{6+}$, ion $\mathrm{Al}^{3+}$, ion $\mathrm{Cu}^{2+}$, ion $\mathrm{Zn}^{2+}$, ion $\mathrm{Fe}^{2+}$, ion $\left(\mathrm{PO}_{4}\right)^{3-}$ ammonia nitrogen and colour ws determined to be $2.678 \mathrm{mg} / \mathrm{mg}, 2.857 \mathrm{mg} / \mathrm{mg}$, $8.058 \mathrm{mg} / \mathrm{mg}, 1.720 \mathrm{mg} / \mathrm{mg}, 6.146 \mathrm{mg} / \mathrm{mg}, 0.032 \mathrm{mg} / \mathrm{mg}$, $0.017 \mathrm{~g} / \mathrm{mg}, 2.010 \mathrm{~g} / \mathrm{mg}$ and $0.468 \mathrm{~g} / \mathrm{mg}$, respectively. Comparing these parameters, the resin affinity sequence seems to be in the order of $\mathrm{NH}_{3}>$ colour $>\mathrm{COD}>$ $\mathrm{Cu}^{2+}>\mathrm{Fe}^{2+}>\mathrm{Al}^{3+}>\mathrm{Cr}^{6+}>\mathrm{Zn}^{2+}>\left(\mathrm{PO}_{4}\right)^{3}$.

However, the value of correlation coefficient, $R^{2}$ displayed an inversely trend, which showed that adsorption of ammonia nitrogen $\left(\mathrm{NH}_{3}-\mathrm{N}\right)$, colour and chemical oxygen demand (COD) on Indion MB 6 SR resin were not adopted in Langmuir isotherm model. In agreement with the hypothesis by Samczynski and Dybczynski (1997), the fit of Langmuir isotherm model for the bindings of COD in carboxylate sites is rarely applicable. Accordingly, Koivula et al. (2000) suggested that the sorption and desorption kinetics and selective loading characteristics of some commercial resins are governed not only by the target metal concentrations, but also by competing adsorbates and changes of the concentrations.

Separation factor, $R_{\mathrm{L}}$ value for the adsorption of ion $\mathrm{Cr}^{6+}$, ion $\mathrm{Al}^{3+}$, ion $\mathrm{Cu}^{2+}$, ion $\mathrm{Zn}^{2+}$ and ion $\mathrm{Fe}^{2+}$ ranged from 0.2 to 0.4 (Table 3), showing that the adsorption process was favourable in all range of resin dosage. $R_{\mathrm{L}}$ value for COD was found to be 0.964 , which is approximately 1 . This means that the adsorption behaviour is proportional to the changes of the resin dosage. For ammonia nitrogen, $R_{\mathrm{L}}$ value was obtained as 0.048 , which is nearly zero. This is attributed to the reason that the adsorption process is highly favourable and irreversible, 
where it can be evidenced by the breakthrough curve result (nearly $90 \%$ removal).

\section{Freundlich isotherm}

Freundlish isotherm gives an expression encompassing the surface heterogeneity and the exponential distribution of active sites along with their energies (Hasany et al. 2002.). Compared to Langmuir isotherm, it showed better fit to the experiment data, especially at lower sorbent loading. For removal of ion $\mathrm{Cr}^{6+}$, ion $\mathrm{Al}^{3+}$, ion $\mathrm{Cu}^{2+}$, ion $\mathrm{Zn}^{2+}$ and ion $\mathrm{Fe}^{2+}$, the correlation coefficient, $R^{2}$ obtained were 0.9324 , $0.9123,0.9866,0.9653$ and 0.8852 , respectively. However, the $R^{2}$ values for $\mathrm{PO}_{4}{ }^{3-}, \mathrm{COD}, \mathrm{NH}_{3}-\mathrm{N}$ and colour of $0.3822,0.4756,0.8364$ and 0.5729 , were found relatively lower than cations earlier. This findings were in accordance to work reported by Dakiky et al. (2002), which stated that the sorption process for anion and organic fraction in the leachate was controlled by diffusion and binding steps. As presented in Table 2, adsorption intensity given by Freundlich coefficient $n$, in all cases lying between 0.2287 and 0.8002 for all the adsorbates studied, represented good sorption potential and high affinity of Indion MB 6 SR resin. Moreover, $n$ value was lower than unity, indicating that the adsorbates were favourably adsorbed. High value of $K_{\mathrm{f}}$ indicated that the binding capacity has reached its highest value. Nevertheless, the model was not applicable to the adsorption of ion $\left(\mathrm{PO}_{4}\right)^{3-}, \mathrm{COD}$ and colour. Even though the correlation coefficient, $R^{2}$, was greatly improved, it appeared that there was no significant effect, where the correlation coefficient, $R^{2}$, lay in the range of 0.3822-0.5729. Accordingly, Hasany et al. (2002) commented that the result could most probably be attributed to the reason that Freundlich isotherm does not predict any saturation of sorbent by the sorbates in its mathematical model, which is not practical in all conditions.

Kinetic study

\section{Pseudo first-order kinetic study}

The kinetics of adsorption describes the rate of ions uptake on ion exchange resins and this rate controls the equilibrium time. The list of adsorption constants on Indion MB 6 SR resin for different adsorbates using pseudo first-order kinetic model is shown in Table 4. As exhibited by Fig. 1, the amounts of ions exchanged increased rapidly at the early stage of experiment, then gradually increased and finally approached constant values for long experimental durations. Final equilibrium ions decreased with the rise of resin dosage used. However, the first-order equation did not apply throughout all the contact times in this work. It was
Table 4 List of adsorption constants on Indion MB 6 SR mixed bed resin for different adsorbates using pseudo first-order kinetic model

\begin{tabular}{|c|c|c|c|c|}
\hline Parameter & $\begin{array}{l}\text { Resin } \\
\text { dosage } \\
(\mathrm{ml})\end{array}$ & $\begin{array}{l}\text { Correlation } \\
\text { coefficient, } R^{2}\end{array}$ & $\begin{array}{l}q_{\mathrm{e}} \\
(\mathrm{mg} / \mathrm{g})\end{array}$ & $\begin{array}{l}\text { Rate constant, } \\
k_{1}\left(\min ^{-1}\right)\end{array}$ \\
\hline \multirow[t]{5}{*}{$\mathrm{Cr}^{6+}$} & 4.00 & 0.9872 & 10.86 & 0.0164 \\
\hline & 8.00 & 0.9842 & 11.26 & 0.0198 \\
\hline & 12.00 & 0.9852 & 8.52 & 0.0207 \\
\hline & 16.00 & 0.9746 & 6.01 & 0.0253 \\
\hline & 20.00 & 0.9719 & 3.08 & 0.0267 \\
\hline \multirow[t]{5}{*}{$\mathrm{Al}^{3+}$} & 4.00 & 0.9912 & 10.48 & 0.0205 \\
\hline & 8.00 & 0.9755 & 11.50 & 0.0212 \\
\hline & 12.00 & 0.9847 & 8.13 & 0.0189 \\
\hline & 16.00 & 0.9862 & 6.19 & 0.0281 \\
\hline & 20.00 & 0.9737 & 3.43 & 0.0313 \\
\hline \multirow[t]{5}{*}{$\mathrm{Cu}^{2+}$} & 4.00 & 0.9725 & 23.20 & 0.0159 \\
\hline & 8.00 & 0.9725 & 22.60 & 0.0159 \\
\hline & 12.00 & 0.9725 & 16.14 & 0.0191 \\
\hline & 16.00 & 0.9561 & 16.14 & 0.0189 \\
\hline & 20.00 & 0.9358 & 12.96 & 0.0184 \\
\hline \multirow[t]{5}{*}{$\mathrm{Zn}^{2+}$} & 4.00 & 0.9727 & 11.64 & 0.0200 \\
\hline & 8.00 & 0.9785 & 17.55 & 0.0200 \\
\hline & 12.00 & 0.9526 & 7.68 & 0.0248 \\
\hline & 16.00 & 0.9351 & 5.46 & 0.0341 \\
\hline & 20.00 & 0.7186 & 3.04 & 0.0191 \\
\hline \multirow[t]{5}{*}{$\mathrm{Fe}^{2+}$} & 4.00 & 0.9603 & 48.98 & 0.0210 \\
\hline & 8.00 & 0.9730 & 51.09 & 0.0223 \\
\hline & 12.00 & 0.9202 & 35.61 & 0.0234 \\
\hline & 16.00 & 0.9114 & 23.27 & 0.0283 \\
\hline & 20.00 & 0.8795 & 12.94 & 0.0134 \\
\hline \multirow[t]{5}{*}{$\mathrm{PO}_{4}{ }^{3-}$} & 4.00 & 0.7575 & 18.29 & 0.0511 \\
\hline & 8.00 & 0.9795 & 485.40 & 0.0175 \\
\hline & 12.00 & 0.9498 & 73.42 & 0.0175 \\
\hline & 16.00 & 0.9156 & 61.26 & 0.0134 \\
\hline & 20.00 & 0.9531 & 66.76 & 0.0168 \\
\hline \multirow[t]{5}{*}{ COD } & 4.00 & 0.9747 & 7643.64 & 0.0200 \\
\hline & 8.00 & 0.9404 & 6458.03 & 0.0216 \\
\hline & 12.00 & 0.9388 & 6567.50 & 0.0219 \\
\hline & 16.00 & 0.9311 & 4497.80 & 0.0233 \\
\hline & 20.00 & 0.9013 & 1935.08 & 0.0329 \\
\hline \multirow[t]{5}{*}{$\mathrm{NH}_{3}-\mathrm{N}$} & 4.00 & 0.8550 & 4119.08 & 0.0557 \\
\hline & 8.00 & 0.8776 & 6332.86 & 0.0613 \\
\hline & 12.00 & 0.8864 & 5693.77 & 0.0730 \\
\hline & 16.00 & 0.9604 & 2379.03 & 0.0700 \\
\hline & 20.00 & 0.9766 & 1157.18 & 0.9886 \\
\hline \multirow[t]{5}{*}{ Colour } & 4.00 & 0.9593 & 10784.49 & 0.9886 \\
\hline & 8.00 & 0.7701 & 18100.89 & 1.0283 \\
\hline & 12.00 & 0.7924 & 13106.90 & 1.0454 \\
\hline & 16.00 & 0.7907 & 21742.03 & 1.0464 \\
\hline & 20.00 & 0.7587 & 5123.89 & 1.0371 \\
\hline
\end{tabular}



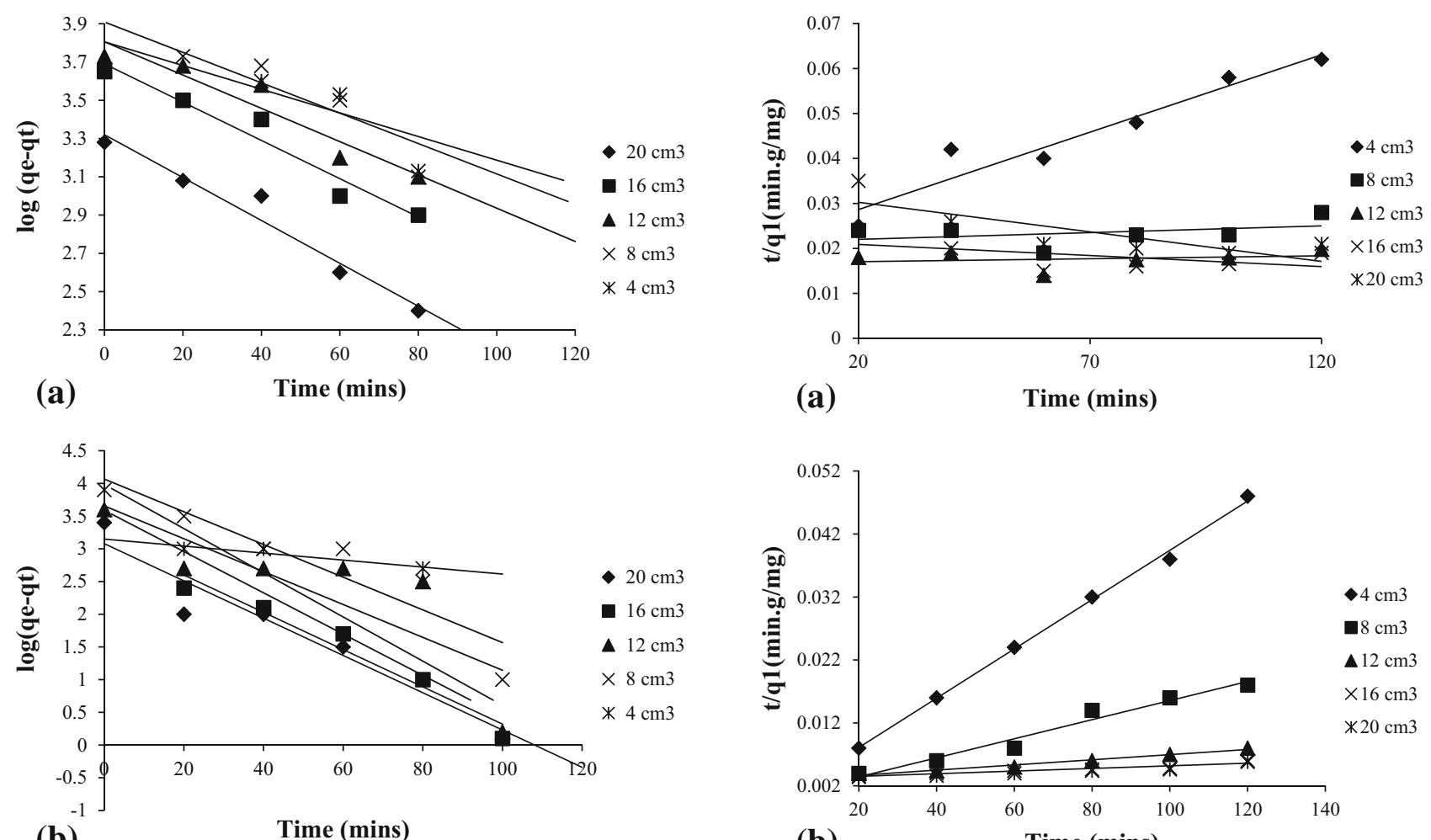

(b)

Time (mins)
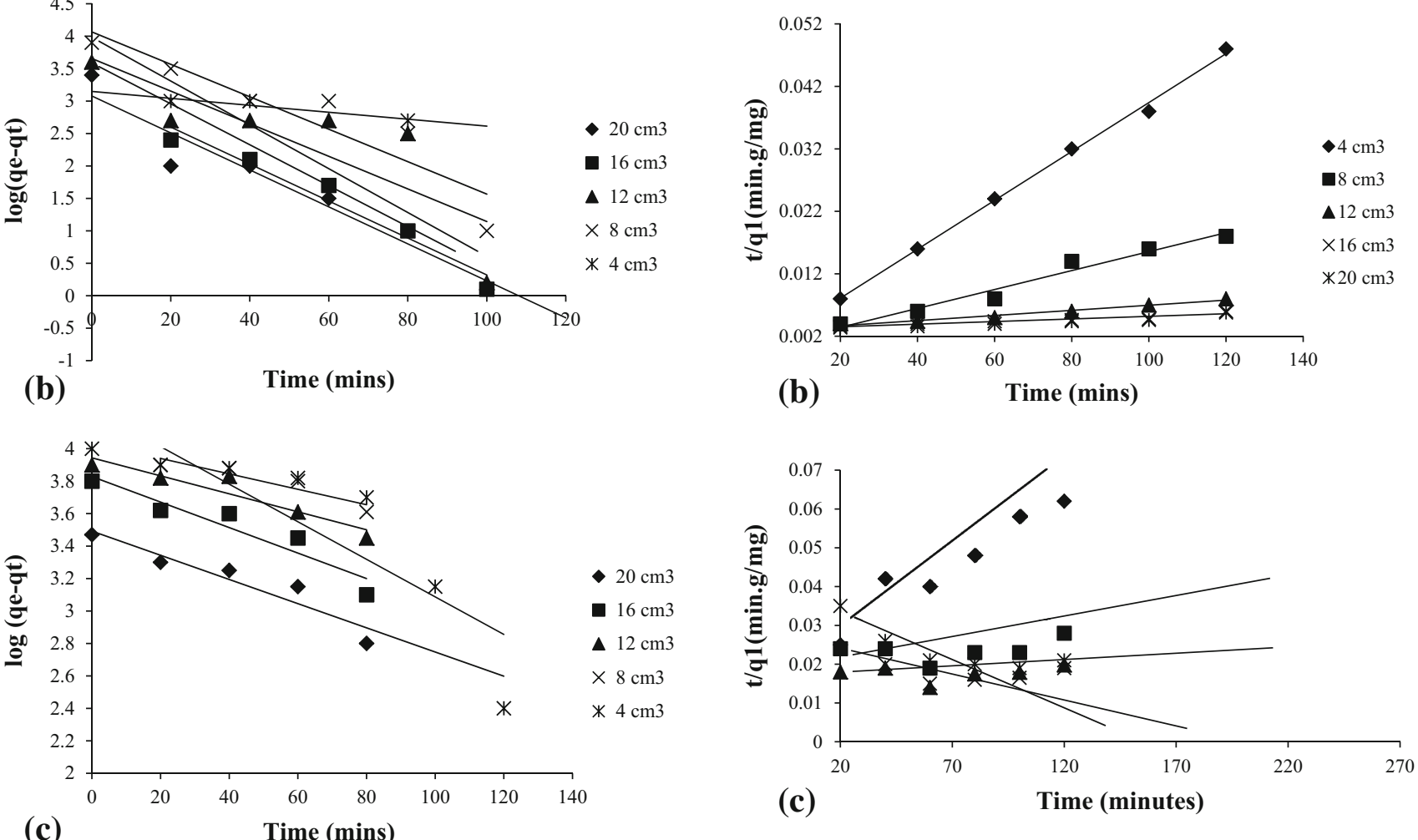

Fig. 1 Pseudo first-order kinetic model for a chemical oxygen demand (COD), b ammonia nitrogen $\left(\mathrm{NH}_{3}\right)$ and $\mathbf{c}$ colour

applicable over the initial 80-min sorption period where plots of $\log (\mathrm{qe}-\mathrm{qt})$ versus time at different adsorbent dosage deviated considerably from the data after a short period.

As shown in Table 3 , the calculated $k_{1}$ values were indrectly proportionally to the resin dosage, indicating that it does not obey the pseudo first-order model. Azizan (2004) concluded that the rate coefficient of pseudo first-order model is a complex function of resin dosage. Furthermore, Azizan and Yantaei (2006) found that the pseudo first-order rate coefficient $\left(k_{1}\right)$ is not intrinsic adsorption rate constant but a combination adsorption $\left(k_{\mathrm{a}}\right)$ and desorption $\left(k_{\mathrm{d}}\right)$ rate constants as shown in Eq. (3.1). Pehlivan and Altun (2007) mentioned that the kinetics may be affected by a number of

Fig. 2 Pseudo second-order kinetic model for a chemical oxygen demand (COD), b ammonia nitrogen $\mathrm{NH}_{3}-\mathrm{N}$ and $\mathbf{c}$ colour

parameters (the nature of exchanger, counter ions and the extent of agitation) that further explained the above deviations.

\section{Pseudo second-order kinetic study}

Figure 2 shows the straight line plots of $t / q_{t}$ versus time for different resin dosage indicated the applicability of pseudo second-order kinetic model. The list of adsorption constants on Indion MB 6 SR resin for different adsorbates using pseudo second-order kinetic model is shown in Table 5. The difference between the correlation coefficient values clearly demonstrated that the data showed a better compliance with pseudo second-order kinetic model with correlation coefficients ranging from 0.7587 to 1.000 . 
Table 5 List of adsorption constants on Indion MB 6 SR resin for different adsorbates using pseudo second-order kinetic model

\begin{tabular}{|c|c|c|c|c|}
\hline Adsorbate & $\begin{array}{l}\text { Resin } \\
\text { dosage } \\
(\mathrm{ml})\end{array}$ & $\begin{array}{l}\text { Correlation } \\
\text { coefficient, } R^{2}\end{array}$ & $q_{\mathrm{e}}(\mathrm{mg} / \mathrm{g})$ & $\begin{array}{l}\text { Rate constant, } k_{2} \\
(\mathrm{~g} / \mathrm{mg} \mathrm{min})\end{array}$ \\
\hline \multirow[t]{5}{*}{$\mathrm{Cr}^{6+}$} & 4.00 & 0.9950 & 3.76 & 0.0143 \\
\hline & 8.00 & 0.9938 & 7.40 & 0.0065 \\
\hline & 12.00 & 0.9978 & 10.83 & 0.0031 \\
\hline & 16.00 & 0.9972 & 14.22 & 0.0022 \\
\hline & 20.00 & 0.9979 & 13.44 & 0.0021 \\
\hline \multirow[t]{5}{*}{$\mathrm{Al}^{3+}$} & 4.00 & 0.9941 & 3.59 & 0.0122 \\
\hline & 8.00 & 0.9905 & 6.83 & 0.0060 \\
\hline & 12.00 & 0.9965 & 10.43 & 0.0025 \\
\hline & 16.00 & 0.9905 & 12.55 & 0.0018 \\
\hline & 20.00 & 0.9956 & 13.50 & 0.0018 \\
\hline \multirow[t]{5}{*}{$\mathrm{Cu}^{2+}$} & 4.00 & 0.9938 & 7.40 & 0.0065 \\
\hline & 8.00 & 0.9972 & 9.03 & 0.0031 \\
\hline & 12.00 & 0.9978 & 10.83 & 0.0022 \\
\hline & 16.00 & 0.9466 & 13.44 & 0.0021 \\
\hline & 20.00 & 0.9978 & 14.22 & 0.0017 \\
\hline \multirow[t]{5}{*}{$\mathrm{Zn}^{2+}$} & 4.00 & 0.9786 & 3.31 & 0.0050 \\
\hline & 8.00 & 0.9755 & 3.91 & 0.0017 \\
\hline & 12.00 & 0.9784 & 12.61 & 0.0005 \\
\hline & 16.00 & 0.9377 & 46.30 & 0.0002 \\
\hline & 20.00 & 0.8891 & 70.42 & 0.0001 \\
\hline \multirow[t]{5}{*}{$\mathrm{Fe}^{2+}$} & 4.00 & 0.9164 & 0.40 & 0.0027 \\
\hline & 8.00 & 0.9547 & 6.35 & 0.0025 \\
\hline & 12.00 & 0.8553 & 41.84 & 0.0003 \\
\hline & 16.00 & 0.9244 & 47.62 & 0.0003 \\
\hline & 20.00 & 0.9587 & 51.81 & 0.0002 \\
\hline \multirow[t]{4}{*}{$\mathrm{PO}_{4}{ }^{3-}$} & 4.00 & 0.9794 & 25.77 & 0.00060 \\
\hline & 12.00 & 0.9259 & 80.00 & 0.00021 \\
\hline & 16.00 & 0.9880 & 80.00 & 0.00014 \\
\hline & 20.00 & 0.8955 & 107.53 & 0.00003 \\
\hline \multirow[t]{5}{*}{ COD } & 4.00 & 0.8690 & $33,33.33$ & $3.91 \times 10^{-6}$ \\
\hline & 8.00 & 0.9167 & $10,000.00$ & $4.68 \times 10^{-7}$ \\
\hline & 12.00 & 0.9137 & $11,111.11$ & $3.00 \times 10^{-7}$ \\
\hline & 16.00 & 0.9278 & $16,666.67$ & $1.62 \times 10^{-7}$ \\
\hline & 20.00 & 0.9186 & $33,333.33$ & $5.59 \times 10^{-8}$ \\
\hline \multirow[t]{5}{*}{$\mathrm{NH}_{3}$} & 4.00 & 0.9999 & $2,500.00$ & 0.00027 \\
\hline & 8.00 & 1.0000 & $5,000.00$ & 0.00013 \\
\hline & 12.00 & 0.9985 & $10,000.00$ & 0.00002 \\
\hline & 16.00 & 0.9993 & $10,000.00$ & 0.00001 \\
\hline & 20.00 & 0.9981 & $10,000.00$ & 0.00002 \\
\hline \multirow[t]{5}{*}{ Colour } & 4.00 & 0.8690 & $5,000.00$ & $1.92 \times 10^{-6}$ \\
\hline & 8.00 & 0.8167 & $14,285.71$ & $2.99 \times 10^{-7}$ \\
\hline & 12.00 & 0.8137 & $20,000.00$ & $2.38 \times 10^{-7}$ \\
\hline & 16.00 & 0.8279 & $33,333.33$ & $2.11 \times 10^{-8}$ \\
\hline & 20.00 & 0.9186 & $50,000.00$ & $8.04 \times 10^{-8}$ \\
\hline
\end{tabular}

Table 6 List of adsorption constants on Indion MB 6 SR mixed bed resin for different adsorbates using Freundlich isotherm model

\begin{tabular}{lllr}
\hline Parameter & $\begin{array}{l}\text { Correlation } \\
\text { coefficient, } R^{2}\end{array}$ & $n$ & $\begin{array}{l}\text { Freundlich } \\
\text { constants, } K_{\mathrm{f}}\end{array}$ \\
\hline $\mathrm{Cr}^{6+}$ & 0.9324 & 0.2945 & $12.91 \mathrm{mg} / \mathrm{g}$ \\
$\mathrm{Al}^{3+}$ & 0.9123 & 0.3381 & $11.78 \mathrm{mg} / \mathrm{g}$ \\
$\mathrm{Cu}^{2+}$ & 0.9866 & 0.4117 & $3.18 \mathrm{mg} / \mathrm{g}$ \\
$\mathrm{Zn}^{2+}$ & 0.9653 & 0.3698 & $7.97 \mathrm{mg} / \mathrm{g}$ \\
$\mathrm{Fe}^{2+}$ & 0.8852 & 0.2396 & $0.04 \mathrm{mg} / \mathrm{g}$ \\
$\mathrm{PO}_{4}{ }^{3-}$ & 0.3822 & 0.8002 & $1.95 \mathrm{mg} / \mathrm{g}$ \\
$\mathrm{COD}^{2+}$ & 0.4756 & 0.3844 & $3.36 \mu \mathrm{g} / \mathrm{g}$ \\
$\mathrm{NH}_{3}$ & 0.8364 & 0.7883 & $8.01 \mathrm{mg} / \mathrm{g}$ \\
$\mathrm{Colour}$ & 0.5729 & 0.2287 & $0.42 \mathrm{dg} / \mathrm{g}$ \\
\hline
\end{tabular}

In the research conducted by Sabir et al. (2006), a relatively high correlation coefficient for pseudo second-order kinetic model was obtained, indicating that the model successfully described the adsorption kinetics. As displayed by Table 6, pseudo second-order rate constant $\left(k_{2}\right)$ decreased consistently with the increased of initial resin dosage where the initial sorption rate was found to increase with the resin dosage. The result is in agreement with the findings of Rengaraj et al. (2007).

Ho and McKay (1999) reported that pseudo secondorder reaction is greatly influenced by the amount of metal on the adsorbent's surface and amount of metal adsorbed at equilibrium. The rate is directly proportional to the number of active surface sites. Thus, chemisorptions of the heterogeneous system might not be correctly defined by the kinetic equation. Although very good linearity is found for these models, calculated results do not agree with the experimental data. Parameters $k_{1}, k_{2}$ and $q_{\mathrm{e}}$ vary with the amount of resin used and the initial concentration. Theoretically, these kinetic parameters should be independent of the reactant concentrations such as resin weight and initial heavy metal concentrations.

In this aspect, even though the models displayed the advantages of their easiness for use, the disadvantages are that the predicted results do not satisfactorily agree with the experimental data and they usually depend on the operating conditions (Pehlivan and Altun 2007). Ho and Mckay (1999) clarified that the kinetics of the ion exchange involve five distinct steps, namely diffusion of ions through the bulk solution, diffusion of ion through hydrated film surrounding the particle, diffusion of ion across the film-particle interface, diffusion of ion through the particle and the actual chemical reaction involving exchange of ions. These processes were affected by a 

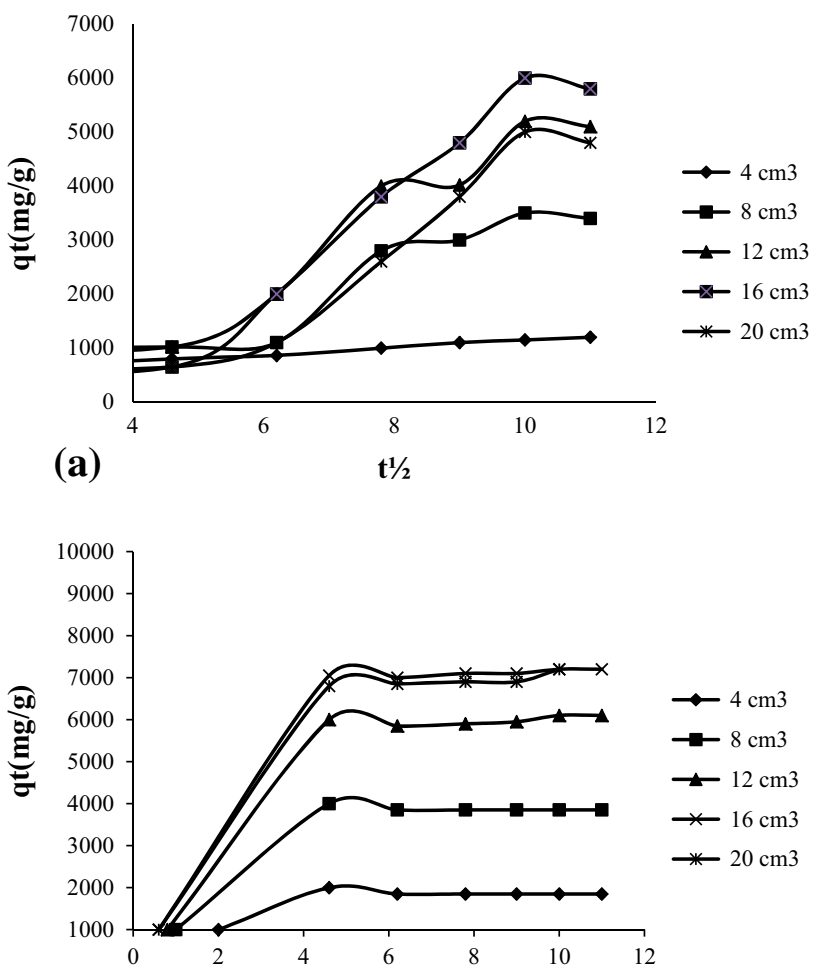

(b)

$\mathbf{t}^{1 / 2}$

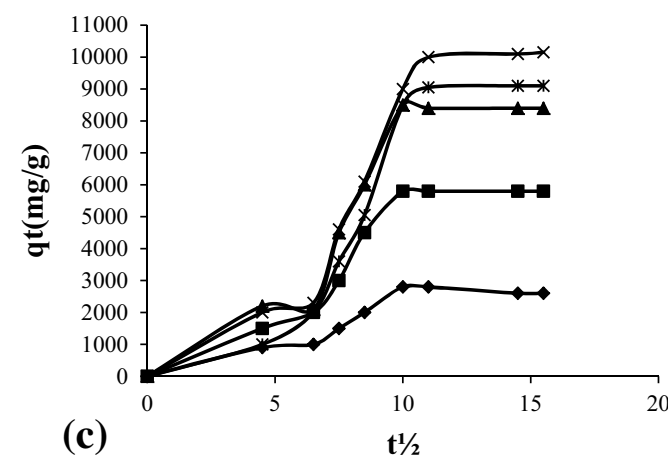

Table 7 List of adsorption constants on Indion MB 6 SR resin for different adsorbates using intraparticle diffusion model

\begin{tabular}{|c|c|c|c|}
\hline Adsorbate & $\begin{array}{l}\text { Resin dosage } \\
\left(\mathrm{cm}^{3}\right)\end{array}$ & $\begin{array}{l}\text { Correlation } \\
\text { coefficient, } R^{2}\end{array}$ & $\begin{array}{l}\text { Rate constant, } k_{\mathrm{id}} \\
(\mathrm{g} / \mathrm{mg} \mathrm{min})\end{array}$ \\
\hline \multirow[t]{5}{*}{$\mathrm{Cr}^{6+}$} & 4.00 & 0.8285 & 0.2205 \\
\hline & 8.00 & 0.8384 & 0.4368 \\
\hline & 12.00 & 0.9016 & 0.6170 \\
\hline & 16.00 & 0.9178 & 0.7957 \\
\hline & 20.00 & 0.9209 & 0.8068 \\
\hline \multirow[t]{5}{*}{$\mathrm{Al}^{3+}$} & 4.00 & 0.8393 & 0.2145 \\
\hline & 8.00 & 0.8478 & 0.4078 \\
\hline & 12.00 & 0.9268 & 0.5891 \\
\hline & 16.00 & 0.9291 & 0.7089 \\
\hline & 20.00 & 0.9348 & 0.7645 \\
\hline \multirow[t]{5}{*}{$\mathrm{Cu}^{2+}$} & 4.00 & 0.8873 & 0.4535 \\
\hline & 8.00 & 0.8664 & 0.8194 \\
\hline & 12.00 & 0.9496 & 1.1599 \\
\hline & 16.00 & 0.9380 & 1.4497 \\
\hline & 20.00 & 0.9438 & 1.4593 \\
\hline \multirow[t]{5}{*}{$\mathrm{Zn}^{2+}$} & 4.00 & 0.8992 & 0.1841 \\
\hline & 8.00 & 0.9137 & 0.3590 \\
\hline & 12.00 & 0.9272 & 0.4999 \\
\hline & 16.00 & 0.8816 & 0.6543 \\
\hline & 20.00 & 0.9081 & 0.6771 \\
\hline \multirow[t]{5}{*}{$\mathrm{Fe}^{2+}$} & 4.00 & 0.8850 & 0.7442 \\
\hline & 8.00 & 0.9093 & 1.5064 \\
\hline & 12.00 & 0.9171 & 2.2321 \\
\hline & 16.00 & 0.8865 & 2.7087 \\
\hline & 20.00 & 0.8856 & 2.7661 \\
\hline \multirow[t]{5}{*}{$\mathrm{PO}_{4}{ }^{3-}$} & 4.00 & 0.9766 & 1.3697 \\
\hline & 8.00 & 0.9861 & 2.7070 \\
\hline & 12.00 & 0.9177 & 3.4893 \\
\hline & 16.00 & 0.9761 & 3.9232 \\
\hline & 20.00 & 0.9809 & 4.2495 \\
\hline \multirow[t]{5}{*}{ COD } & 4.00 & 0.9792 & 176.27 \\
\hline & 8.00 & 0.9384 & 396.36 \\
\hline & 12.00 & 0.8621 & 549.91 \\
\hline & 16.00 & 0.9237 & 576.65 \\
\hline & 20.00 & 0.8964 & 650.34 \\
\hline \multirow[t]{5}{*}{$\mathrm{NH}_{3}-\mathrm{N}$} & 4.00 & 0.8981 & 190.35 \\
\hline & 8.00 & 0.8990 & 375.01 \\
\hline & 12.00 & 0.8341 & 555.70 \\
\hline & 16.00 & 0.8758 & 690.71 \\
\hline & 20.00 & 0.8572 & 696.07 \\
\hline \multirow[t]{5}{*}{ Colour } & 4.00 & 0.8726 & 219.01 \\
\hline & 8.00 & 0.8719 & 453.96 \\
\hline & 12.00 & 0.8682 & 663.79 \\
\hline & 16.00 & 0.8634 & 788.35 \\
\hline & 20.00 & 0.8896 & 802.35 \\
\hline
\end{tabular}

Fig. 3 Intraparticle diffusion model for a chemical oxygen demand (COD), b ammonia nitrogen (NH3) and c colour

number of parameters and may not be exactly represented by any model.

\section{Intraparticle diffusion model}

For a solid-liquid sorption process, the solute transfer is usually characterized by external mass transfer (boundary layer diffusion), or intraparticle diffusion or both (Sarkar et al. 2003). The plot of $q_{\mathrm{t}}$ versus $t^{0.5}$ as shown in Fig. 3 represents different stages of adsorption. The list of adsorption constants on Indion MB 6 SR resin for different adsorbates using intraparticle diffusion model is shown in 
Table 7. An initial steep-sloped portion is followed by a linear portion to the intraparticle diffusion and a plateau to the equilibrium. In this context, initial steep-sloped portion (from 0 to $60 \mathrm{~min}$ ) is attributed to the external surface adsorption or instantaneous adsorption, while gentle-sloped portion (from 60 to $240 \mathrm{~min}$ ) is associated with the gradual adsorption.

This revealed that intraparticle diffusion is rate-controlled and leads to a plateau to the equilibrium. However, intraparticle diffusion started to slow down due to extremely low solute concentration in solution. In agreement with the study performed by Rengaraj et al. (2007), the rate constant, $k_{\text {id, }}$ of the intraparticle diffusion model was higher at the higher resin dosage. Accordingly, Wu et al. (2004) proposed that if the two steps are independent of one another, the plot of $q_{t}$ versus $t^{0.5}$ appears as a combination of two or more intersecting lines. Hereby, the surface adsorption and intraparticle diffusion were likely to take place simultaneously, where both processes controlled the kinetics of resin-ion interaction. The pores and steps on the resin particles were such that they could accommodate the ion phosphate $\left(\mathrm{PO}_{4}\right)^{3-}$ molecules.

\section{Conclusion}

From the batch study, it was observed that Langmuir fit for ion metals is good with correlation coefficient $R^{2}$ in the range of $0.85-0.97$. The maximum monolayer coverage capacities, $Q_{\mathrm{o}}$, increased proportional to the amount of resin dosage. However, the adsorption of ammonia nitrogen, colour and COD was not applicable to the Langmuir isotherm model. Compared to Langmuir isotherm, Freundlich isotherm showed better fit to the experiment data. The adsorption intensity coefficient $n$, lying between 0.2287 and 0.8002 for all the adsorbates studied, represents good sorption potential and high affinity of the Indion MB 6 SR mixed bed resin. For all the systems studied, the intraparticle diffusion model, pseudo first-order and pseudo second-order isotherm models provide the best correlation of the experimental data. Conclusively, the analysis provided important information for designing and modelling the processes.

Acknowledgments This work has been funded by Universiti Sains Malaysia through Research Grant (RUI 100/PAWAM/614166).

Open Access This article is distributed under the terms of the Creative Commons Attribution License which permits any use, distribution, and reproduction in any medium, provided the original author(s) and the source are credited.

\section{Appendix}

$1 / q_{\mathrm{e}}=1 / Q_{0}+1 / K_{\mathrm{L}} Q_{\mathrm{o}} C_{\mathrm{e}}$

$\log q_{\mathrm{e}}=\log K_{\mathrm{f}}+1 / n \log C_{\mathrm{e}}$

$\log \left(q_{\mathrm{e}}-\mathrm{q}_{\mathrm{t}}\right)=\log \left(q_{\mathrm{e}}\right)-\left(k_{1} / 2.303\right)$

$t / q_{t}=\left(1 / \mathrm{K}_{2}\left(q_{\mathrm{e}}\right)^{2}\right)+\left(1 / q_{\mathrm{e}}\right)$

$q_{t}=k_{\mathrm{id}} t^{0.5}$

$K_{1}=K_{\mathrm{a}} C_{\mathrm{o}}+K_{\mathrm{d}}$

\section{References}

Ahn WY, Kang MS, Yim SK, Choi KH (2002) Advanced landfill leachate treatment using an integrated membrane process. Desalination 149:109-114

Al-Hamadani YAJ, Yusoff MS, Umar M, Bashir MJK, Adlan MN (2011) Application of psyllium husk as coagulant and coagulant aid in semi-aerobic landfill leachate treatment. J Hazard Mater 190:582-587

APHA (2005) Standard Method for the Examination of Water and Wastewater, 21st edn. American Public Health Association

Aziz HA, Adlan MN, Zahari MSM, Alias S (2004) Removal of ammoniacal-nitrogen $\left(\mathrm{N}-\mathrm{NH}_{3}\right)$ from municipal solid waste leachate by using activated carbon and lime stone. Waste Manag Res 22:371-375

Aziz SQ, Aziz HA, Yusoff MS, Bashir MJK, Umar M (2010) Leachate characterization in semi-aerobic and anaerobic sanitary landfills: A comparative study. J Environ Manage 91:2608-2614

Azizan S, Yahyaei B (2006) Adsorption of 18-crown-6 from aqueous solution on granular activated carbon: a kinetic modeling study. J Coll Interface Sci 229:112-115

Azizian S (2004) Kinetic models of sorption: a theoretical analysis. J Coll Interface Sci 276:47-52

Bashir MJK, Isa MH, Kutty SRM, Awang ZB, Aziz HA, Mohajeri S, Farooqi IH (2009) Landfill leachate treatment by electrochemical oxidation. Waste Manage 29:2534-2541

Bashir MJK, Aziz HA, Yusoff MS, Aziz SQ, Mohajeri S (2010) Stabilized sanitary landfilled leachate treatment using ionic resin: treatment optimization by response surface methodology. J Hazard Mater 182:115-122

Bashir MJK, Aziz HA, Yusoff MS (2011) New sequential treatment for mature landfill leachate by cationic/anionic and anionic/cationic processes: Optimization and comparative study. J Hazard Mater 186:92-102

Cavaco SA, Fernandes S, Margarida MQ, Licinio MF (2007) Removal of chromium from electroplating industry effluents by ion exchange resins. J Hazard Mater 144:634-638

Christensen TH, Kjeldsen PK, Bjerg PL, Jensen DL, Christensen JB, Baun A, Aldrechtsen HJ, Heron G (2001) Review: biogeochemistry of landfill leachate plumes. Appl Geochem 16:659-718

Cortez S, Tiexiera P, Olivera R, Mota M (2011) Evaluation of Fenton and ozone-based advanced oxidation processes as mature landfill leachate pre-treatments. J Environ Manage 92:749-755

Dakiky M, Khamis M, Manassra A, Mereb M (2002) Selective adsorption of chromium(VI) in industrial wastewater using lowcost abundantly available adsorbents. Adv Environ Res 6:533-540 
Foul AA, Aziz HA, Isa MH, Hung YT (2009) Primary treatment of anaerobic landfill leachate using activated carbon and limestone: batch and column studies. Int J Environ Waste Manag 4:282-298

Grebenyuk VD, Verbich SV, Linkov NA, Linkov VM (1998) Adsorption of heavy metal ions by aminocarboxyl ion exchanger ANKB-35. Desalination 115:239-254

Hasany SM, Saeed MM, Ahmed M (2002) Sorption and thermodynamic behavior of zinc(II)-thiocyanate complexes onto polyurethane foam from acidic solution. J Radioanal Nucl Chem 252:477-484

Ho YS, McKay G (1999) Pseudo-second order model for sorption processes. Process Biochem 34:451

Honjiang L, Youcai Z, Lei S, Yingyig G (2009) Three-stage aged refuse biofilter for the treatment of landfill leachate. J Environ Sci 21:70-75

Igoni AH, Ayotamuno MJ, Ogaji SOT, Probert SD (2007) Municipal solid-waste in Port Harcourt, Nigeria. Appl Energy 84:664-670

Jorgensen TC, Weatherley LR (2003) Ammonia removal from wastewater by ion exchange in the presence of organic contaminations. Water Res 37:1723-1728

Kamaruddin MA, Yusoff MS, Aziz HA, Basri NK (2013) Removal of COD, ammoniacal nitrogen and colour from stabilized landfill leachate by anaerobic organism. Appl Water Sci 3(2):359-366

Kamaruddin MA, Yusoff MS, Aziz HA, Hung YT (2014). Sustainable treatment of landfill leachate. Appl Water Sci: pp 1-14

Karadag D, Tok S, Akgul E, Turan M, Ozturk M, Demir A (2008) Ammonium removal from sanitary landfill leachate using natural Gördes clinoptilolite. J Hazard Mater 153:60-66

Kiefer R, Kalinitchev AI, Holl WH (2007) Column performance of ion exchange resins with aminophosphonate functional groups for elimination of heavy metals. React Funct Polym 67:1421-1432

Koivula R, Lehto J, Pajo L, Gale T, Leinonen H (2000) Purification of metal plating rinse waters with chelating ion exchangers. Hydrometallurgy 56:93-108

Kulikowska D, Klimiuk E (2008) The effect of landfill age on municipal leachate composition. Bioresour Technol 99:5981-5985

Kurniawan TA, Lo WH, Chan GYS (2006) Physico-chemical treatments for removal of recalcitrant contaminants from landfill leachate. J Hazard Mater 129:80-100

Leakovic S, Mijatovic I, Cerjan-Stefanovic MS, Hodzic E (2000) Nitrogen removal from fertilizer wastewater by ion exchange. Water Res 34:185-190

Lee IH, Yu CK, Jia MC (2006) Equilibrium and kinetics of heavy metal ion exchange. J Chin Inst Chem Eng, 38:71-84

Li XZ, Zhao QL, Hao XD (1999) Ammonium removal from landfill leachate by chemical precipitation. Waste Manag 19:409-415

Marttinen SK, Kettunen RH, Rintala JA (2003) Occurrence and removal of organic pollutants in sewages and landfill leachates. Sci Total Environ 301:1-12

Nanny MA, Ratasuk N (2002) Characterization and comparison of hydrophobic neutral and hydrophobic acid dissolved organic carbon isolated from three municipal landfill leachates. Water Res 36:1572-1584

Pehlivan E, Altun $\mathrm{T}$ (2007) Ion-exchange of $\mathrm{Pb}^{2+}, \mathrm{Cu}^{2+}, \mathrm{Zn}^{2+}, \mathrm{Cd}^{2+}$, and $\mathrm{Ni}^{2+}$ ions from aqueous solution by Lewatit CNP 80 . J Hazard Mater 140:299-307
Poznyak T, Bautista L, Cordova RI, Rios LE (2007) Decomposition of toxic pollutants in landfill leachate by ozone after coagulation treatment. J Hazard Mater 152:1108-1114

Rengaraj S, Yeon JW, Kimb Y, Jung Y, Haa YK, Kim WH (2007) Adsorption characteristics of $\mathrm{Cu}(\mathrm{II})$ onto ion exchange resins $252 \mathrm{H}$ and 1500H: Kinetics, isotherms and error analysis. J Hazard Mater 143:469-477

Renou S, Givaudan JG, Poulain S, Dirassouyan F, Moulin P (2008) Landfill leachate treatment: Review and opportunity. J Hazard Mater 150:468-493

Sabir H, Hamidi AA, Hasnain I, Nordin A, Faridah AH (2006) Physico-chemical method for ammonia removal from synthetic wastewater using limestone and GAC in batch and column studies. Bioresour Technol 98:874-880

Salem Z, Hamouri K, Djemaa R, Allia K (2008) Evaluation of landfill leachate pollution and treatment. Desalination 220:108-114

Samczynski Z, Dybczynski R (1997) Some examples of the use of amphoteric ion-exchange resins for inorganic separations. J Chromatogr A 789:157-167

Sarkar M, Acharya PK, Battacharya B (2003) Modeling the adsorption kinetics of some priority organic pollutants in water from diffusion and activation energy parameters. J Colloid Interf Sci 266:28-32

Sauck WA (2000) A conceptual model for the geoelectrical response of LNAPL plumes in granular sediments. J Appl Geophys 44:151-165

Silva AC, Dezotti M, Sant'Anna GL (2004) Treatment and detoxification of a sanitary landfill leachate. Chemosphere 55:207-214

Smara A, Delimi R, Chainet E, Sandeaux J (2007) Removal of heavy metals from diluted mixtures by a hybrid ion-exchange/electrodialysis process. Sep Purif Technol 57:103-110

Tan Y, Kildu JE, Kitis M, Karanfil T (2005) Dissolved organic matter removal and disinfection byproduct formation control using ion exchange. Desalination 176:189-200

Tatsi AA, Zouboulis AI, Matis KA, Samaras P (2003) Coagulationflocculation pretreatment of sanitary landfill leachates. Chemosphere 53:737-744

Turan M, Gulsen H, Celik MS (2005) Treatment of landfill leachate by a combined anaerobic fluidized bed and zeolite column system. J Environ Eng ASCE 131:815-819

Umar M, Aziz HA, Yusoff MS (2010) Variability of parameters involved in leachate pollution index and determination of LPI from four landfills in Malaysia. Int J Chem Eng 2010:1-6. doi: $10.1155 / 2010 / 747953$

Warith M (2002) Bioreactor landfills: experimental and field results. Waste Manag 22:7-17

Woodberry P, Stevens G, Northcott K, Snape I, Stark S (2007) Field trial of ion-exchange resin columns for removal of metal contaminants, Thala Valley Tip, Casey Station, Antarctica. Cold Reg Sci Technol 48:105-117

Wu JJ, Wu CC, Ma HW, Chang CC (2004) Treatment of landfill leachate by ozone-based advanced oxidation processes. Chemosphere 54:997-1003

Zagorodni AA (2006) Ion exchange materials: properties and applications. Elsevier publisher, online Book 2 83: pp 15-18 